\title{
Milroy disease
}

INSERM

\section{Source}

INSERM. (1999). Orphanet: an online rare disease and orphan drug data base. Milroy

disease. ORPHA:79452

Milroy disease is a frequent form of primary lymphedema (see this term) characterized generally by painless, chronic lower-limb lymphedema found at birth or developing in the early neonatal period. 